\section{Psihologia ca profesie şi deontologia intervențiilor psihologice în managementul resurselor umane}

Horia D. Pitariu

Ioan Radu

Universitatea Babeş-Bolyai, Cluj Napoca
Psihologia ca ştiință şi profesia de psiholog

Profesia de psiholog, la fel ca oricare alta, presupune respectarea unor norme deontologice, aceasta cu atât mai mult cu cât obiectul principal al intervențiilor psihologilor îl formează ființa umană. Or, psihologii, prin natura profesiei lor, trebuie să se implice activ în respectarea intimității şi a integrității psihice a fiecărei persoane, să promoveze şi să protejeze drepturile fundamentale ale omului. Psihologii, prin profesia pe care o practică, sunt preocupați de îmbogățirea cunoştințelor despre comportamentul uman, de înțelegerea propriilor manifestări şi ale altora, de utilizarea cunoştințelor ştiințifice de psihologie pentru promovarea unei integrări optime socioprofesionale. Deşi psihologia este considerată o ştiința relativ tânără, ea a realizat, in cei peste 100 de ani de existență progrese remarcabile, dovedindu-şi utilitatea oriunde este prezent omul: la locul de muncă, în şcoală, în clinică, în viața politică, în armată etc. De-a lungul timpului s-au conturat numeroase fundamentări teoretice cu consecințe aplicative sau structuri interpretative care au revoluționat societatea. Psihologia stucturalistă, freudismul, behaviorismul, şi mai recent psihologia cognitivă s-au dovedit a fi modalități de abordare a psihicului şi a comportamentului uman cu repercusiuni benefice asupra calității vieții psihice a oamenilor. Dar, poate ceea ce este demn de subliniat este faptul că psihologii prin aplicațiile practice în care s-au implicat, întotdeauna şi-au fixat ca obiectiv fundamental optimizarea acțiunilor factorului uman, sprijinirea nemijlocită a oamenilor, indiferent în ce postură ar fi ei: elev, muncitor, militar, manager sau client. $O$ intervenție de natură psihologică, oricare ar fi natura ei, de orientare profesională, consiliere psihologică, selecție profesională, evaluarea profesională etc. rămâne imprimată in mintea beneficiarului mulți ani după epuizarea evenimentului respectiv. Campbell (1974) a arătat că o acțiune de consiliere de orientare profesională, nu numai că marchează viața profesională a unui tânăr, dar constituie un eveniment pe care acesta şi-I aminteşte şi după 20 de ani cu o fidelitate destul de mare. Autorii acestui studiu s-au confruntat adesea cu situații în care persoanele cu care au interacționat au povestit despre inițiativele Oficiilor de Orientare Profesională din anii 1940, la distanță de 30 de ani. Se sublinia atât profesionalismul cu care 
au fost conduse intervențiile psihologice, cât şi obiectivitatea psihologului în luarea unor decizii legate de rezultatele examenului de orientare şi selecție profesională sau de optimizări de natură ergonomică.

\section{Pericole prezente cu care ne confruntăm}

În ultima perioadă de timp, practicile de psihologie aplicată din țara noastră au cunoscut o expansiune foarte mare. Acest lucru a fost determinat, în mare măsură, de procesul tranziției socio-economice prin care trecem, de cerințele obiective de schimbare a mentalităților şi structurilor social-economice depăşite, precum şi de expansiunea industrială, penetrarea pe piața românească a capitalului străin şi integrarea noastră în procesul de internaționalizare economică şi implicit a forței de muncă. Anii recenți ne-au confruntat cu numeroase probleme de natură socială cum ar fi creşterea masivă a prezenței companiilor multinaționale, o migrație masivă a forței de muncă în contextul în care a crescut impactul cu tehnologiile noi şi a companiilor dotate cu o infrastructură modernă. Deci, condițiile unei solicitări în sfera psihologiei aplicate sunt prezente, dar specialiştii sunt puțini şi profesionalismul lor este adesea lacunar, chiar submediocru. Desigur, aici o contribuție semnificativă 0 are sistemul de învățământ universitar care este incapabil să asigure o pregătire eterogenă, de calitate absolvenților din domeniul psihologiei. Acest aspect a fost relevat de către Colegiul Psihologilor care face eforturi să suplinească lipsa de profesionalism a psihologilor practicieni instituind 0 serie de trepte de acreditare şi de formare profesională prin sisteme de supervizare. Au fost organizate în acest sens cursuri de perfecționare postuniversitară, un sistem de supervizare a debutanților în psihologia muncii şi organizațională, s-a stimulat participarea la conferinte şi workshop-uri etc.

În interventia de față ne vom restrânge atenția numai la aplicațiile psihologiei în aria industrială/organizațională, sau a resurselor umane, domeniu care a fost supus în ultimul timp unor deformări conceptuale şi metodologice flagrante. Fenomenul nu este nou. Pecaud (1959) menționa că în Franța postbelică, firmele de consultanță şi psihologii de ocazie au apărut ca "ciupercile după ploaie". Paterson (1930), la timpul său, menționa că în lupta cu şarlatanii care profită de fisurile psihologiei ştiințifice şi promovează practici psihologice de estradă, lipsite de fundamentare ştiințifică (frenologia, morfopsihologia, psihobioritmurile, astrologia, horoscopul etc.), este important să se lupte cu armele pe care psihologia ştiințifică le pune la dispoziție. Despre aceşti pseudopsihologi discută şi Anastasi (1979), care atrage atenția într-o manieră foarte serioasă asupra pericolului pe care aceştia îl reprezintă pentru societate. La noi în țară s-a luat încă de mult atitudine față de imixtiunile nespecialiştilor în psihologie şi față de practicile diletante (Pitariu, Boştenaru, Lucaciu, Oachiş, 1982; Podină, 1992). Fireşte, Asociația Psihologilor din România, prin statutul său şi Colegiul Psihologilor, promovează o psihologie ştiințifică, astfel au fost elaborate o serie de norme deontologice care reglementau modalitățile de practicare a psihologiei şi exigențele de utilizare a instrumentarului psihodiagnostic (Herseni, 1969; Radu, 1976, vezi şi colecția Psihologia Resurselor Umane). Din nefericire, multe din aceste realizări au fost date uitării sau pur şi simplu neglijate cu bună ştiință, aplicațiile psihologice fiind invadate de pseudopsihologi. (Este regretabil că mijloacele mass-media, în special televiziunea, acordă, de pildă, astrologiei un spațiu prea mare care nu are nimic de-a face cu unul din obiectivele majore ale acesteia, educarea maselor. În aceeaşi măsură, popularizarea unor practici neştiințifice de genul paranormalului sau "calităților” unor ghicitoare considerăm că reprezintă o limită serioasă şi o abatere flagrantă de la principiile normelor ştiințifice despre lume şi viață). Aceştia, din nefericire, nu pot fi stopați prin nici un act juridic. Erorile care se fac în prezent pe această linie sunt grave, iar repercusiunile în timp vor fi dezastruoase. $O$ mențiune în ce priveşte practicarea psihologiei de către psihologi. Profesia de psiholog este protejată de Legea psihologului. Dar acest lucru obligă psihologul şi la o justificare ştiințifică a acțiunilor pe care le întreprinde. De pildă, selecția profesională, examenul psihologic, în general, indiferent că se face pe baza unui interviu sau teste psihologice, trebuie fundamentată ştiințific. Orice persoană care a fost supusă unui examen psihologic are dreptul să cunoască rezultatul deciziei psihologului. $O$ decizie pe bază de teste sau alte instrumente de predicție psihologice, poate fi atacată în instanță, psihologul fiind dator să justifice validitatea instrumentelor utilizate. Auzim deseori că la un examen psihologic de selecție a managerilor sa utilizat ca probă desenul unui copac şi testul 
culorilor al lui Lüscher (ierarhizarea a opt culori în ordinea preferinței), probă contestată datorită absenței unor studii serioase de validare, dar şi a unor probe nerelevante cu functia de manager sau alta (mai recent, la interviuri li se cere candidaților să relateze "cum se vor vedea peste cinci ani" - ne întrebăm ce predictivitate are un răspuns la această întrebare?). Indiferent de proba psihologică utilizată, psihologul trebuie să cunoască şi să-şi bazeze decizia pe calitățile predictive ale acesteia, adică să demonstreze că între rezultatele la proba/testul utilizată şi performanța profesională există 0 relație corelațională. Simpla utilizare a unor probe psihologice selecționate pe bază de „etichetă” este o eroare gravă. „Flerul” psihologului este un mit.

\section{Managementul Resurselor Umane - o abordare multidisciplinară}

Psihologia aplicată la nivel organizațional este adesea considerată ca o parte a managementului resurselor umane $(\mathrm{MRU})$. Este necesară această subliniere deoarece la noi în țară se consideră greşit că MRU este o problemă aferentă exclusiv ştiințelor economice, treptat universitățile politehnice încep să dezvolte şi ele secțiile lor de MRU. În acest sens au fost editate o serie de cărți care analizează problema MRU de pe poziții adesea strict teoretice, din care reiese diletantismul autorilor în problemele de selecție profesională, evaluarea personalului sau instruirea profesională. Realitatea este că MRU este o disciplină cu conotații multidisciplinare; problemele salarizării, ale planificării forței de muncă sau de structură a companiilor este firesc să le discute economiştii. Orientarea şi reorientarea profesională, selecția, evaluarea sau instruirea profesională, motivația şi satisfacția cu munca aparțin psihologiei personalului. Aici pot fi incluse şi problemele de psihologie organizațională, de fapt, departamentul de resurse umane al unei organizații trebuie să includă un personal mixt, economişti, psihologi şi persoane de alte specialități, în funcție de specificul organizației respective. Acest personal poate acoperi fiecare segment de activitate în care este pregătit.

\section{Situații contestate de psihologie si psihologi}

Literatura de specialitate din domeniul MRU este vastă, o dovadă a interesului pe care un domeniu îl solicită într-o economie de piață şi un cadru capitalist în care se pune problema gestionării personalului. Puținele lucrări de care dispunem în momentul de față în acest domeniu consideră necesară apelarea la traduceri. Din nefericire, unele traduceri de cărți cu conținut MRU sunt de neînțeles din cauza terminologiei psihologice deformate. Astfel, lucrarea prestigioasă a lui Johns (1998) utilizează un limbaj psihologic 'inedit', de nepătruns pentru psihologi şi specialiştii din resurse umane, periculos pentru cititori (feedback $=$ consolidare, validitate $=$ valabilitate, fidelitate=reliabilitate etc.). Recomandarea acestei traduceri ca material bibliografic va duce la formarea unui specialist al cărui limbaj ştiințific pentru a fi înțeles va solicita o adevărată muncă de decriptare. Desigur, o mare vină aparține în acest caz editorului care a renunțat la părerile unor referenți. Cazul citat nu este unic.

Firmele de consultanță pe probleme de resurse umane sunt o necesitate şi o practică răspândită pe plan internațional. Printre activitățile pe care aceste firme le promovează, există pachete de oferte cu conținut specific psihologic. Faptul că personalul acestor firme este adesea şcolarizat în străinătate, urmând cursuri intensive, este un aspect important, dar când acest personal (ingineri, economişti ş.a.) se crede apt să facă o selecție profesională cu o metodologie specifică universal valabilă, este un abuz sau, simplu spus, o impostură. Un psiholog este şcolarizat în prezent timp de trei ani şi poate să-şi continue studiile în cadrul unui program de master sau alte cursuri speciale postuniversitare sau doctorale. $\mathrm{Cu}$ toate acestea, adevărații psihologi care sunt angajați într-o astfel de firmă, sunt adesea tratați ca „neexperimentați” sau „lipsiți de experiență" şi sunt puşi în situația să suporte o serie de „sugestii” şi „,̂ndrumări” care excelează prin incompetență (nesupunerea are ca şi consecință renunțarea la serviciile lor).

În mod obişnuit oferta firmelor de consultanță se rezumă la următoarele activități:

- Recrutarea şi selecția profesională ;

- Cursuri de instruire pe diferite teme ;

- Diagnoze organizaționale ;

- Proiectarea de sisteme de evaluare a personalului.

Cele mai acute probleme se ridică în legătură cu recrutarea şi selecția profesională unde asistăm la un abuz de teste psihologice şi practici neştiințifice. Mulți dintre 
pseudopsihologii de care vorbeam, dacă au reuşit să achiziționeze unul sau mai multe teste psihologice ori chestionare de personalitate, au impresia ca acestea sunt suficiente, că au dreptul să le utilizeze (uneori intr-o manieră strict personală), fără să ia în considerare problemele de validitate, fidelitate sau de normare. Din nefericire chiar mulți psihologi au făcut rabat de la utilizarea ştiințifică a instrumentarului psihodiagnostic. Anastasi (1979), autor al unor lucrări de referință de psihodiagnostic, observa: testele psihologice nu pot fi aplicate corect în afara contextului psihologic. Instrumentul uneori uitat al cunoaşterii psihologice este psihologul însuşi. Testul aduce informații despre subiect într-o formă codificată. Cotele sau indiciile calitative obținute in cadrul unei examinări nu explică un nivel de performanță, un fapt de conduita. Psihologul urmează să desprindă din datele brute informațiile relevante. Esențial este să nu se desprindă nici mai multe, nici mai puține informații decât cele reale, cuprinse în datele obținute. Utilizarea de probe psihologice şi, cu atât mai mult, elaborarea unor noi teste presupune o competență precisă, care îmbină o anumită tehnicitate cu finețea observației. Ne vom aştepta ca în viitor să ne confruntăm cu o adevărată revoltă antitest (este ceva similar cu ceea ce s-a întâmplat în prin anii '50 în unele țări occidentale. Interviul de selecție a ajuns instrumentul preferat al diletanților în MRU. Soarta unui candidat oarecare rămâne la latitudinea dispozițiilor şi subiectivismului unui selecționer obscur, lipsit adesea de cele mai elementare cunoştințe psihologice şi de tehnica de derulare a unui interviu. Interviul de selecție este considerat în literatura psihologică drept un mijloc de selectie care în anumite cazuri are o validitate mai redusă. EI posedă însă calitatea de a fi utilizat în prezent cu frecventa de cea mai mare. Valoarea interviului de selecție este apreciabilă numai in situații bine determinate şi alături de alte mijloace de psihodiagnoză. Dar, fenomenul cel mai condamnabil apare în situația în care firmele de consultanță şi unii psihologi utilizează instrumentarul psihologic pentru a disponibiliza personalul unei organizații. Astfel, se încalcă unul din principiile cele mai elementare ale codului deontologic al psihologilor. Psihologul are ca principal obiectiv sprijinirea oamenilor în a se integra într-un anumit loc de muncă, optimizarea participării la muncă, medierea conflictelor dintre patronat şi ceilalți salariați etc. De-a lungul timpului, psihologii şi-au bazat intervențiile de optimizare a serviciilor şi de sprijin al angajaților pe date ştiințifice. Printre primii care au sărit în ajutorul celor care lucrau la banda rulantă sau pe care se experimentau metode tayloriene de muncă, mărirea arbitrară a zilei de muncă etc., au fost psihologii care prin studiile pe care le-au efectuat au demonstrat aportul incontestabil al umanizării muncii.

Despre cursurile de instruire oferite de către firmele de consultanță putem afirma, desigur fără a generaliza, faptul că de cele mai multe ori acestea oferă "teme de curs" de genul Cum motivăm angajații, Cheia succesului în afaceri, Tehnici de evaluare a personalului etc. Rareori oferta are la bază o analiză a trebuințelor de instruire, neinteresând nici maniera de receptare (evaluare) a cursului şi a efectelor acestuia. Frecvent, la astfel de cursuri întâlnim prezentarea unei teme al cărei suport de curs a fost tradus mai mult sau mai puțin corect şi care este prezentat sumar, lectorul confundând suportul de curs cu cursul propriu-zis. Indicația „prețioasă” este „pentru a fi mai avizați în problemă, citiți suportul de curs". Alteori, după câteva exerciții puerile, cărora li se mai spune ,joc de rol” (jocul de rol este o tehnica de instruire, dar care se desfăşoară după anumite reguli), se consideră că s-au format deprinderi manageriale, de vânzare etc. (uneori termenul de „deprindere” nu este cunoscut, formatorii susținând că formează "skilluri"!).

Schimbarea organizațională, fenomen specific dinamicii oricărei organizații presupune realizarea unei diagnoze organizaționale. Aceasta înseamnă o abordare sistemică a organizației, realizată de o echipă multidisciplinară de specialişti. Diagnoza organizațională include, ca parte componentă a analizei, segmentul uman al organizației, acesta fiind privit ca unul dintre cele mai importante. Există în acest context o metodologie de analiză complexă bazată pe modele, teorii şi realizată prin interviuri şi chestionare consacrate. Dar, evaluarea resurselor umane este cu totul impropriu, de-a dreptul revoltător, să se facă pe baza unor puncte sau note, aşa cum pretind unele metodologii. Nu putem nota nivelul de motivatie al angajaților cu un calificativ de 6 sau sistemul de conducere cu nota 3 , acesta cu atât mai mult cu cât nu există nici un cadru de referință. Este bine să se înțeleagă că astfel de investigații presupun existența unei metodologii de lucru care poate varia de la o 
organizație la alta şi se face cu un instrumentar specializat.

Despre aprecierile de personal, evaluarea performanțelor profesionale ale salariaților, se pot spune multe. Aceasta este o practica mai veche, astăzi peste $90 \%$ din companiile occidentale au în aplicare unul din sistemele de apreciere propuse de către psihologi. Acest lucru este specific şi țării noastre, multe companii utilizând un anumit sistem de apreciere anuală sau bianuală a salariatilor. La noi in tara a existat o lege in acest sens si mai recent o serie de hotărâri guvernamentale (HG) care încearcă sa revigoreze această practică atât de utilă conducerii eficiente a unei companii. Trecând peste erorile conținute de HG-urile respective şi care le fac adesea neoperaționale, aceasta pentru că psihologii specializați pe problematica evaluărilor nu au fost consultați, s-a ajuns la soluții de-a dreptul hilare. O idee bună şi necesară s-a transformat într-o acțiune de un formalism acut. Un sistem de apreciere a personalului este 0 investiție serioasă, implementarea sa fiind dependentă de specificul companiei, a locului de muncă ocupat si nu o măsură cu aplicabilitate universală. lată, se prevede în normativele în circulație să se noteze "cantitatea şi calitatea muncii". Acestea sunt două dimensiuni care trebuie evaluate separat. Apoi, se pretinde notarea "creativității"- dimensiune profesională care nu se poate nota într-un loc de muncă în care se cere respectarea cu strictețe a unor instrucțiuni de execuție (ce ar fi dacă un pilot al unui avion de pasageri s-ar abate de la traseul de zbor pentru că este o zi cu soare si priveliştea din avion ar încânta pasagerii? Pasagerii ar aprecia pozitiv ideea pilotului, dar acesta s-ar alege cu o sancțiune severă pentru acțiunea sa "creativă"). Odată cu măsura de a evalua performanțele angajaților, numeroase firme de consultanță au obținut subvenții de pe proiecte finanțate din exterior pentru a-i învăța pe alții cum să-şi construiască sistemul de evaluare respectiv. Eroarea aparține în primul rând celor care au evaluat aceste proiecte, apoi celor care le-au obținut şi care nu ştiu cum se realizează un astfel de proiect. A dezvolta un proiect de evaluare a personalului înseamnă a declanşa o acțiune de investigare după o metodologie bine pusă la punct. Psihologul este chemat să facă investigațiile necesare pe teren, sistemul de evaluare fiind concluzia unor intervenții succesive. In niciun caz sistemul de evaluare nu trebuie să fie doar creația unui director de departament de resurse umane sau a unui inginer ori economist. Aceştia vor fi eventual instruiți ca evaluatori şi vor fii invitați ca experți în construirea sistemului de evaluare a personalului.

\section{Experiența altor țări}

Abuzurile pseudopsihologilor, a diletanților în managementul resurselor umane şi chiar a unor psihologi incompetenți sunt 0 realitate recunoscută de numeroase țări. Acesta este motivul pentru care în ultimul timp asociațiile naționale ale psihologilor, organismele internaționale care au fost create, psihologii înşişi, acordă o importanță din ce in ce mai mare implementării unui cadru absolut legal acțiunilor pe care le întreprind. Discuții ample au fost purtate de către Asociația Psihologilor Americani in reviste ca American Psychologist şi Asociația Psihologilor din Franța (1996). Codurile deontologice ale acestor asociații ne pot servi ca punct de plecare în întregirea a ceea ce a fost realizat şi la noi in țară într-un timp nu prea îndepărtat (Herseni, 1969; Radu, 1976).

Asociația Psihologilor Americani a adoptat în anul 1992 ceea ce a devenit Ethical Principles of Psychologists and Code of Conduct (1992). Altfel, psihologii americani au subscris la respectarea unor principii profesionale grupate in următoarele domenii: Responsabilitate, Competență, Moralitate şi standarde legale, Declarații publice, Confidențialitate, Mulțumirea beneficiarilor, Relațiile profesionale, Tehnici de evaluare, Cercetarea cu subiecți umani, Precauții şi Utilizarea animalelor în cercetări. Aceste teme de interes surprind drepturile şi îndatoririle psihologilor, principiile după care aceştia trebuie să-şi deruleze activitatea lor profesională. Abaterile de la aceste norme sunt pedepsite atât de asociațiile profesionale cât şi pe cale juridică instituționalizată.

Asociația Psihologilor Francezi are un cod deontologic propriu şi specificații pentru fiecare ramură mare a psihologiei: Psihologia muncii, Psihologia educațională, Psihologia clinică şi Psihologia socială aplicată. Leplat (1971) a sintetizat codul etic a psihologilor industriali.

\section{Câteva recomandări:}

În exercitarea profesiei sale psihologul îşi interzice orice act sau cuvânt care aduce atingerea demnității persoanei umane. El trebuie să fie conştient de necesitatea de a fi 
obiectiv şi circumspect când acțiunea sa operează cu noțiuni ca normal-anormal, adaptat-dezadaptat etc., care afectează persoane şi relații interpersonale.

Psihologul este supus regulii secretului profesional; această regulă priveşte concluziile, rapoartele, documentele redactate în codul deontologic al profesiei sale. Toate demersurile sale se fac cu respectul demnității persoanei care face obiectul intervenției sale.

Munca psihologului practician se face in spiritul datelor cercetărilor din domeniu; el trebuie să caute şi să aplice criterii şi metode controlabile din punct de vedere ştiințific. De asemenea, psihologul trebuie să refuze orice angajament pe care starea prezentă a tehnicilor de lucru nu i-ar permite să şi-o asume.

Practic, psihologul operează într-un mediu tehnic în care trebuie să posede orientarea necesară. Acțiunea sa vizează adaptarea angajatului la mediul său, arătându-i limitele personale care I-ar expune la riscuri de accident, dar şi capacitățile sale care-i asigură promovarea, succesul. Psihologul trebuie să ajute pe cel examinat să-şi dea seama de propriile sale obiective şi să le realizeze în timp. Clasificând împreună cu subiectul datele situației - notează Leplat (1971) - îl va ajuta să-şi adapteze deciziile şi să le compatibilizeze cu obiectivele urmărite. Se înțelege că psihologul garantează calitatea metodelor şi tehnicilor utilizate şi cunoaşte limitele acestora. În ultimul timp se discută tot mai frecvent despre o simbioză practică-ştiință sub formula scientist-practitioner. Ştiința luminează practica, iar aceasta produce ştiință. Practicianul nu este doar deținătorul unei colecții de rețete sau rutine pe care doar deținătorul le aplică indefinit. Aceasta rămâne o imagine de istorie.

\section{Bibliografie}

Anastasi , A. (1979). Fields of Applied Psychology. NY: McGraw-Hill.

Campbell, D.P. (1974). Give me one of those interest tests so I can see what I should be. In: Measurement for Self Understanding and Personal Development (9-13). Proceedings of the 1973 Invitational Conference on Testing Problems. Educational Testing Service, Princeton, New Jersey.

*** Ethical Principles of Psychologists and Code of Conduct. (1992). American Psychologist, 47, 12, 1597-1611.
Herseni, T. (1969). Laboratorul uzinal de psihologie, sociologie si pedagogie. Editura Ştiințifică, Bucureşti.

Johns, G. (1998). Comportament organizațional. Înțelegerea şi conducerea oamenilor în procesul muncii. Bucureşti: Editura Economică.

Leplat, J. (1971). Deontologie de la psychologie du travail. In: M. Reuchlin (coord.), Traite de psychologie appliqué (183-194). Paris: Boulevard Saint-Germain.

Pacaud, S. (1959). La selection Professionnelle. Paris: P.U.F.

Paterson, D.G. (1930). Psysique and intellect. NY: The Century Co.

Pitariu, H., Boştenaru, N., Lucaciu, L., \& Oachiş, A. (1982). The theory and practice of biorhythms are not confirm. Revue Roumaine des Sciences Sociales. Serie de Psychologie. 26, 2, 149-154.

Podina, V. (1992). Justifică horoscopul încrederea ce i se acordă? Psihologia, 21-23.

Radu, I. (1976). Principii metodologice în elaborarea şi utilizarea probelor psihologice. Revista de psihologie, 22, 1-33 